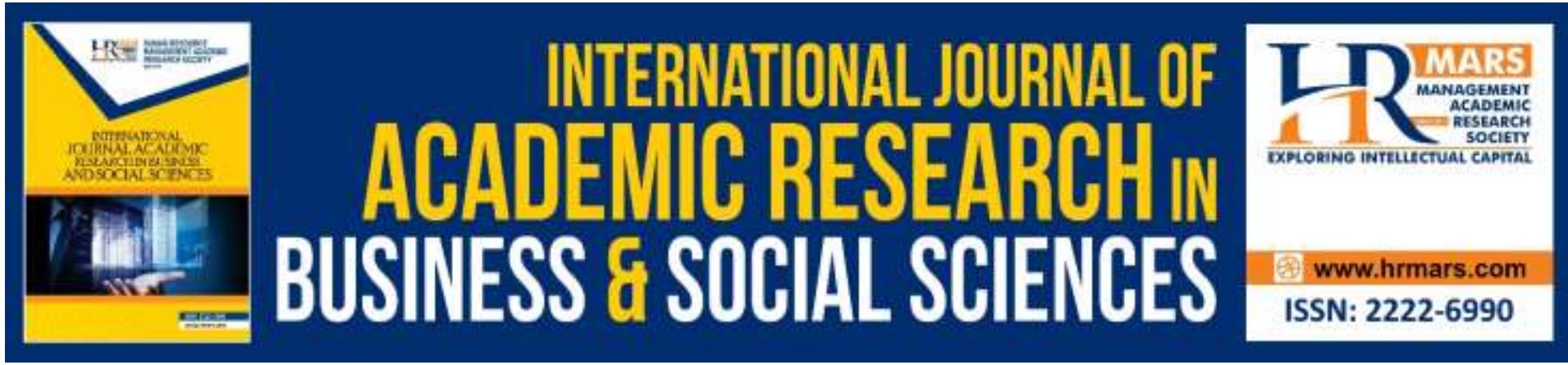

\title{
Complementary Roles of Domestic and International Networks in Sustaining Internationalization of SMEs: a Modeling Approach
}

Ahmed Ibrahim Karage, Raja Nerina Raja Yusof, Devika Nadarajah \& Mohani Abdul

To Link this Article: http://dx.doi.org/10.6007/IJARBSS/v9-i8/6235 DOI: $10.6007 /$ IJARBSS/v9-i8/6235

Received: 22 June 2019, Revised: 10 July 2019, Accepted: 01 August 2019

Published Online: 23 August 2019

In-Text Citation: (Karage, Yusof, Nadarajah, \& Abdul, 2019)

To Cite this Article: Karage, A. I., Yusof, R. N. R., Nadarajah, D., \& Abdul, M. (2019). Complementary Roles of Domestic and International Networks in Sustaining Internationalization of SMEs: a Modeling Approach. International Journal of Academic Research in Business and Social Sciences, 9(8), 200-218.

Copyright: (C) 2019 The Author(s)

Published by Human Resource Management Academic Research Society (www.hrmars.com)

This article is published under the Creative Commons Attribution (CC BY 4.0) license. Anyone may reproduce, distribute, translate and create derivative works of this article (for both commercial and non-commercial purposes), subject to full attribution to the original publication and authors. The full terms of this license may be seen at: http://creativecommons.org/licences/by/4.0/legalcode

Vol. 9, No. 8, 2019, Pg. 200 - 218

Full Terms \& Conditions of access and use can be found at http://hrmars.com/index.php/pages/detail/publication-ethics 


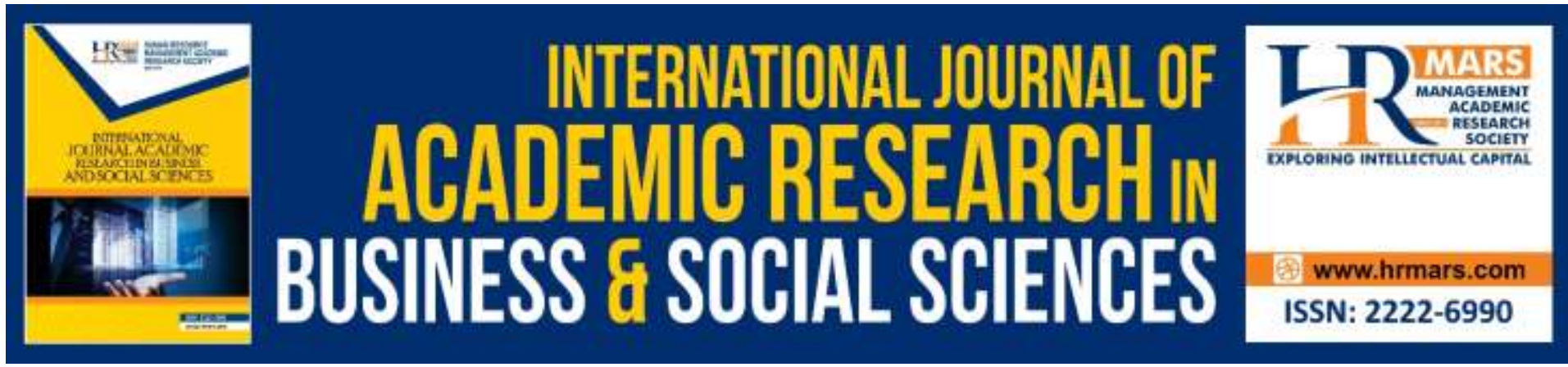

\title{
Complementary Roles of Domestic and International Networks in Sustaining Internationalization of SMEs: a Modeling Approach
}

\author{
${ }^{1}$ Ahmed Ibrahim Karage, ${ }^{2}$ Raja Nerina Raja Yusof, ${ }^{3}$ Devika \\ Nadarajah \& ${ }^{2}$ Mohani Abdul \\ ${ }^{1}$ Faculty of Social and Management Sciences, Yobe State University, Nigeria/Putra, Business \\ School \\ Email: ahmed.phd15@grad, putrabs.edu.my \\ ${ }^{2}$ Faculty of Economics and Management, Universiti Putra Malaysia \\ Email: nerina@upm.edu.my, mohani3242@gmail.com \\ ${ }^{3}$ Putra Business School \\ Email: devika@putrabs.edu.my, ahmed.phd15@grad.putrabs.edu.my
}

\begin{abstract}
The importance of networks in internationalization has been acknowledged in literature with much emphasis on international networks. What remains unclear is the complimentary role being played by domestic and international networks in entry and sustaining international market. This paper provides an empirical understanding of the joint influence of firm's domestic network and international network in sustaining internationalization of SMEs in Sub Sahara African countries. The study also examined the role of international entrepreneurial orientation (IEO) in mediating the relationships between domestic network, international network and internationalization of SMEs. The objectives of the study were achieved by developing hypotheses relating to the network resources in domestic and international markets and internationalization of SMEs. Using partial least square (PLS), the study analyzed data from a sample of 266 exporting SMEs in Nigeria and shows that establishing and maintaining domestic and international networks are crucial in sustaining internationalization of SMEs. Furthermore, mediation effect of IEO was significant in the relationships. The study proposes that enhancing the capacity of exporting SMEs in IEO can further increase their capacity develop and sustain their network resources both at home and in international market.
\end{abstract}

Keywords: Internationalization of SMEs, International Entrepreneurial Orientation, Domestic Network, International Network, Nigeria 


\section{Introduction}

Small and medium enterprises depend on several types of resources than larger companies in achieving strategic goals like internationalization. One of the vital resources they depend on is their network resources (Felzensztein, Ciravegna, Robson, \& Amorós, 2015). Such networks are very important for the fact that markets in developing economies are unstable with lots of institutional impediments. Past studies have established that relationships development with international partners remain the major factor in starting the internationalization process by firms (Hohenthal, Johanson, \& Johanson, 2014; Kontinen \& Ojala, 2011). Similarly SMEs can create domestic relationships engaging as brokers between firms and partners in international markets, commencing relationships on the basis of social ties (O'Gorman \& Evers, 2011), family associates (Coviello, 2006), institutional and technological connections (Evers \& Knight, 2008), and even relations with physically nearby firms (Fletcher, 2008). This means that SMEs can attain central status by progressively linking with firms that are equally trying to attain a central position. Such firms would be able to offer valuable resource to the domestic network such as status, or other internal resources which will enable SMEs to possess substantial number of associates and subsequently become an agent that connect the other firms, getting more attraction and prepare better towards international relationships. Additionally, firms enhance international relationships by involving into different domestic network (Montoro-Sanchez et al., 2018). Internationalization requires firms' diversity in home environment, because such diversity enable SMEs to be connected domestically with companies that have a varied but related knowledge there by exposing them to new opportunities to further enable new combinations of ideas that are essential in their international presence. SMEs with developed domestic network also are more innovative in products and processes, and adapting better to international markets. They also enhance their capacity in understanding and coordination together with partners at international markets (Montoro-Sanchez et al., 2018). The extent of a firm internationalization is determined by the degree to which it occupies in national and foreign networks positions and the level of relevance and integration of the positions (Ratajczak-mrozek, 2014)

This study relied on the works of scholars who argue that researches on networks and internationalization have basically concentrated on international networks (Lamotte \& Colovic, 2015; Sanberg, 2014). However, it is unclear if both domestic and international networks simultaneously help entrepreneurs to internationalize to close neighboring countries and the extent of global internationalization strategy (Felzensztein et al., 2015). Similarly, Montoro-Sanchez et al., (2018) conclude that for SMEs to enhance their international relationships, they require to strengthen gradually strategic positions in the home market network. This paper therefore, add to the literature by making insight into how SMEs combine domestic network resource and those of international market to develop and sustain their resource base for competitive advantage. The paper further shows that IEO as a mechanism that transmits the effect of Domestic and international networks on the internationalization of SMEs in Sub Sahara African countries. The remaining part of the article is structured into theoretical framework which is presented in section two. Section three discusses the measurement of the variables. Section four presents the results obtained and finally, section five draws the discussion, conclusions and suggestion future research. 


\section{Literature Review and Research Hypothesis}

Small and Medium Enterprises were perceived to be less competitive within international markets relative to bigger firms mainly due their inadequate resources such as finance, management capacity, time, market information and technological skills and knowledge. Even after commencing international operations they continue to encounter several challenges in their overseas operations, by being exposed to uncertainties and risk associated to international market (Lin \& Chaney, 2007). Because of these challenges, they become reliant on networks, at the domestic or at international levels on clients, customers, institutions and government bodies to make up for the weakness of limited resources (Hohenthal et al., 2014).

\section{Domestic Network}

Relationship established by firms with other firms within the home country is crucial in attaining competitiveness in internationalization of SMEs. The role of domestic networks on creating international relationships contributes in two strands. First, it provides firms technical knowledge regarding variety of local sources that will enable them to be competitive and second, the firms establish easily new networks by exploiting prior experiences because they have already acquired how to create local network (Montoro-Sanchez et al., 2018). Furthermore, SMEs can overcome their foreignness liability in foreign markets through the developed network among domestic firms and institutions. Within domestic clusters, companies establish diverse relationships with other institutions and firms on basis of formal agreements, trust-based relationships, family-based contact, commercial transactions, informal interaction, etc., providing opportunities to them to establish valuable exchanges and combinations of knowledge (Montoro-Sanchez et al., 2018).

As SME participates in the domestic network, it can incorporate and accumulate the knowledge for international transactions (Milanov \& Fernhaber, 2014) and therefore, for a firm to effectively build a relationship in the international market, it has to develop strong experience from domestic market(Molina-morales \& Teresa, 2010), In a similar manner, SMEs with established domestic network can offer foreign markets with better and more specialized products due to highly qualified staff, a wider network of suppliers, better service and market dealers, formation of business associations with professionalism, large skilled labor formation. Besides business network relations, institutional network links also gives benefit to companies in emerging economies. Institutional network relations are ties with numerous home institutions like officials of government and agencies, universities, financial institutions and banks as well as with trade associations.

Based on resource dependence view (Sullivan \& Ford, 2014), institutional networks constitute resources that enable firms to operate in a market. Thus institutional links are very influential in developing countries where businesses face interference from national and local governments in issues relating to outward FDI (Marinova, Child, \& Marinov, 2015). In addition to relationship with governments, ties with professional bodies and domestic trade unions can offer professional information on various markets places and means of accessing the markets for international transactions. Similarly, due to credit profile deficiency and the liability of being in foreign countries, it is tough for emerging-market companies to obtain financial backing in their host countries. Moreover, the systems of banking in most emerging countries depend on relation to offer long-term loans. Therefore ties with financial 
institutions in domestic market are another valued resource that companies need in order to achieve internationalization. Studies focusing on domestic network revealed that domestic networking of Bulgarian SMEs was found to be related to a higher percentage of international sales (Manolova, Manev, \& Gyoshev, 2010).

This paper tries to offer understanding on the extent to which domestic ties with other institutions and firms influence internationalization of SMEs. Therefore, the following hypothesis was formulated:

$\mathrm{H}_{1}$. Domestic network is positive and significantly related internationalization of SMEs

\section{International Networks}

Network research has been explained as focusing on understanding of various interconnections between units (Oparaocha, 2015). Internationalization network is described as the relationships that exist between management team of a firm and its employees with suppliers, competitors, customers, government agencies, bankers, distributors, families, friends and any other person or group that facilitates its internationalization (Zain \& NG, 2006). Among the stakeholders identified in the description of internationalization networks are various types of institutional players; government agencies, corporate or business networks (Oparaocha, 2015). Johanson \& Vahlne (2009) assert that international connection is the basis of entry into foreign markets. International networks trigger internationalization by providing firms with vital knowledge about international markets thus, helping them to overcome negative perception linked to internationalization. International networks prepare a firm for further penetration into international markets. Fink \& Kraus (2007) found that a network tie with partners in foreign market was related to successful internationalization of SMEs in Czech and Slovenia. Thus the following hypothesis was proposed;

$\mathrm{H}_{2}$ : International network is positive and significantly related to internationalization of SMEs

\section{Mediating effect of International Entrepreneurial Orientation}

International entrepreneurial orientation (IEO) expresses the ability of a firm to engage in some innovativeness, undertake fairly risky activities and be proactive in innovations which influence and support international entrepreneurship from cross cultures as well as from a cross country perspective

(Wach, 2015). Empirical evidence indicates that EO measures are related to firms that show better performance in their domestic and foreign markets (Felzensztein, Ciravegna, \& Robson, 2015). Each new entry to market is an indication of entrepreneurial act involving risk taking, innovativeness, and proactive characteristics and indeed, there is an increasing focus on firm's tendency at engaging in innovativeness and risk-taking activities towards promoting competitiveness in foreign markets. (Swoboda \& Olejnik, 2016)

Argument put forward by this study is that international entrepreneurial orientation of a firm is a potential mediator variable in relationship between firm's domestic networks and international network and internationalization of SMEs. This is because internationalization involves higher levels of uncertainty (Johanson \& Vahlne, 2009), and which requires commitment in considerable risk taking by entrepreneurs as they seek opportunities in foreign markets. It seems common in the literature of international entrepreneurship to adopt the main fundamentals of strategic orientations, that is proactiveness and 
innovativeness in relation to international transaction (Dimitratos, Voudouris, Plakoyiannaki, \& Nakos, 2012). It is also an autonomous actions aimed at outdoing rivals, in an attempt to discover, evaluate, and exploit opportunities in foreign market (Sundqvist, Kyläheiko, Kuivalainen, \& Cadogan, 2012).

Thus, in line with Preacher \& Hayes, (2008), the study builds the mediation hypotheses as follows:

$\mathrm{H}_{3}$ : International Entrepreneurial Orientation mediates the relationship between Domestic Networks and Internationalization of SMEs

$\mathrm{H}_{4}$ : International Entrepreneurial Orientation mediates the relationship between International Networks and Internationalization of SMEs

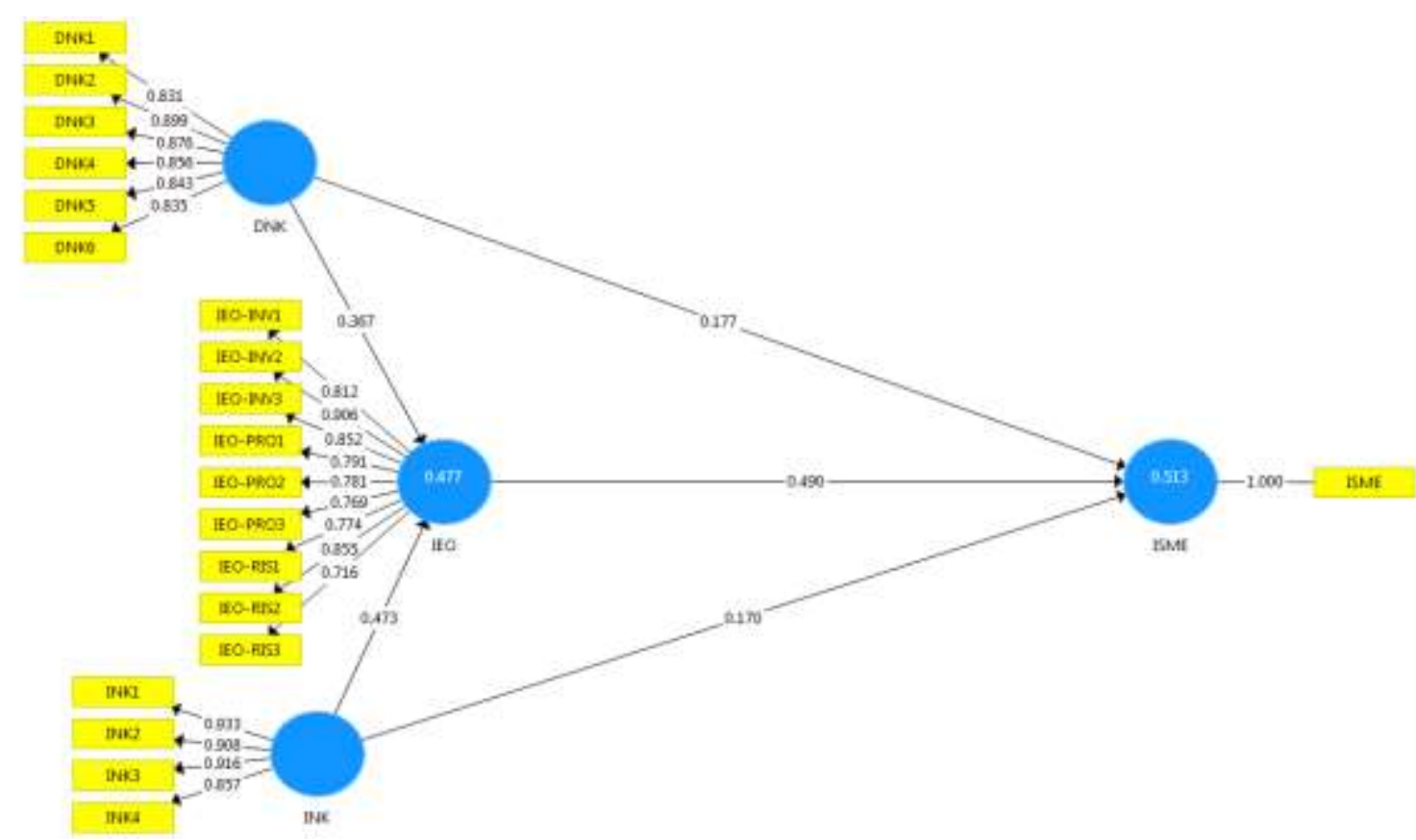

Figure 1: The Research Model showing path coefficient

\section{Research Methods}

In order to have answers to the hypotheses developed for the research and to validate the proposed model, the researchers designed a quantitative study and collected data by means of surveys from entrepreneurs of exporting SMEs in Nigeria. The procedure for measuring instruments used, and sampling techniques are discussed.

\section{Data Collection and Sample}

The researchers' sample was obtained from the Nigerian exporting SMEs listed in Nigerian Export Promotion Council (NEPC). In track with earlier studies on networking and acquisition of knowledge (Simonin, 1997), CEOs of the SMEs was a primary source of information in the study. It was on the basis of the assumption that CEO can provide information about their firms better. However, the study provides for the subordinate of the CEO to respond on the CEO's directives. Five managers selected to pre-test the questionnaire to give an assessment of the face validity. Minor changes in wording were made from their observations and inputs. 
Consent letters stating our research aims and assuring respondents of confidentiality was sent to the CEOs of the 529 identified firms. One hundred and twelve (112) letters retuned as "undeliverable" so the researchers emailed the questionnaires to the remaining potential respondent firms with the option of filling the questionnaire online via prepared Google form. A follow up letters sent after two weeks and subsequently again with another follow up later after another two weeks. Total of 272 responses were received, representing $65 \%$ response rate. This rate was adequate considering the response rate from other studies in transition economies (Fink, Harms, \& Kraus, 2008). Six firms were excluded from the data file because of significant missing data; more than $15 \%$ (Joseph F. Hair, Hult, Ringle, \& Rstedt, 2017). This gave in a final sample of 266 firms.

\section{Measures}

Seven-point Likert scale questionnaire was used for the collection of data for all the construct of the study except the dependent construct which is a single item construct with dichotomous scale. The instruments used were all applied or developed and tested by previous studies and were adapted to measure internationalization of SMEs in Nigeria. The questionnaires were constructed on the basis of multiple item measurement scale previously used by other studies (Felzensztein et al., 2015 and Knight et al., 2015)

\section{Domestic Network}

Holm, Eriksson, \& Johanson, (1996) defined network as involving "set of two or more connected exchange relationship". The network within a home country give an advantage for internationalizing venture (Lee, Yin, Lee, Weng, \& Peng, 2014). Networks were originally measured on a continuum variable from 0 to 9 (Felzensztein, Ciravegna, Robson, \& Amorós, 2015). Respondents were requested to mention individual or organization that supported them through their internationalization process in home country. The question reads "In the process of internationalization of the firm, which of the following institutions and organizations had been essential to the development of internationalization" Export Promotion agency, National exporters association, private institutions, Universities, national companies, Business Incubators ( $a=0.85$ )

\section{International Network}

Internationalization network is described as the relationships between management team of a firm and employees with suppliers, customers, competitors, distributors, government agencies, bankers, families, friends or any other person or group that supports firm to enter into foreign market (Zain \& NG, 2006). This instrument is adapted from Pla-Barber \& EscribáEsteve (2006) with four items-supplier, customer, competitors and institutional networks. It measures network components of stakeholders and services in supporting the development of international activities, knowledge capacities and resource control of a firm (Szyliowicz \& Galvin, 2010) (a=80).

\section{International Entrepreneurial Orientation}

Entrepreneurial orientation of a firm explains firm's attribute in engaging in innovativeness, undertake fairly risky ventures and involve in proactive innovations (Khalili, Nejadhussein, \& Fazel, 2013).This measure is adopted from the work (Covin \& Sleven, 1989) with a total of nine (9) items. Entrepreneurs will be requested to evaluate to what level they agree or 
disagree with the items on the measure with regard to their entrepreneurial activities and perception of foreign market. It measures how a firm is pursue an opportunity in the international market and is associated with managerial vision, innovativeness, risk taking and proactive competitive posture $(a=79)$

\section{Internationalization of SMEs}

Percentage of international sale to total sale is the most regularly used to capture international performance effectiveness (Yoeh, 2004). It has been a viable proxy for degree of internationalization (Kumar \& Singh, 2008). The dependent variable will therefore takes the value of one (1) if foreign sales of SMEs are greater than $25 \%$; otherwise, it is zero (0) (Javalgi \& Todd, 2011)

\section{Data Analysis, Interpretation and Results}

In analyzing the research framework, the study applied Partial Least Squares with structural equation modeling (PLS-SEM) technique for analysis with SmartPLS 3.2.7 software (Ringle et al. 2015). The researchers tested the measurement model involving reliability and validity measures, and then followed by examining the structural model to test the hypothesized relationships (Hair et al. 2014). Bootstrapping was applied to test the significance of the loading and the path coefficients (Hair et al., 2017).

\section{Measurement Model Evaluation}

The study examined the validity of the measurement model by assessing both convergent and discriminant validities. Discriminant validity explains the extent to which items measure dissimilar concepts from one another and was examined based on Fornell \& Larcker (1981) and Hetrotrait-Monotrait (HTMT). Convergent validity is being determined by assessing the average variance extracted (AVE), loadings, and composite reliability (Gholami et al. 2013). In this study all the loadings were found to be above 0.7 , the composite reliabilities also were all above 0.7 and the AVE values were above 0.5 as proposed by (Hair et al., 2017) (see Table 1). In table 2 , the factor loadings for each item in the related construct are in every case higher than they loads on other latent factors, hence convergent validity has been established in this measurement model. 
INTERNATIONAL JOURNAL OF ACADEMIC RESEARCH IN BUSINESS AND SOCIAL SCIENCES Vol. 9, No. 8, August, 2019, E-ISSN: 2222-6990 @ 2019 HRMARS

Table 1 Result of the Measurement Model

\begin{tabular}{lllll}
\hline Constructs & Items & Loadings & AVE & CR \\
\hline Domestic Networks & DNK1 & 0.831 & 0.735 & 0.943 \\
& DNK2 & 0.899 & & \\
& DNK3 & 0.876 & & \\
& DNK4 & 0.856 & & \\
& DNK5 & 0.843 & & \\
Entrepreneurial Orientation & DNK6 & 0.835 & & \\
& IEO1 & 0.812 & 0.944 \\
& IEO2 & 0.9063 & & \\
& IEO3 & 0.852 & & \\
& IEO1 & 0.791 & & \\
& IEO2 & 0.781 & & \\
International Networks & IEO3 & 0.769 & & \\
& IEO1 & 0.774 & & \\
& IEO3 & 0.855 & & \\
& IEO3 & 0.716 & & \\
InK1 & 0.933 & 0.817 & \\
& INK2 & 0.908 & & \\
& INK3 & 0.916 & & \\
& INK4 & 0.857 & & \\
& ISME & 1 & & \\
\hline
\end{tabular}

Average variance extracted (AVE), Composite reliability (CR) 
Table 2 Loading and cross loading

\begin{tabular}{lrrrr}
\hline & DNK & IEO & INK & ISME \\
\hline DNK1 & $\mathbf{0 . 8 3 1}$ & 0.44 & 0.303 & 0.454 \\
DNK2 & $\mathbf{0 . 8 9 9}$ & 0.434 & 0.324 & 0.419 \\
DNK3 & $\mathbf{0 . 8 7 6}$ & 0.504 & 0.345 & 0.49 \\
DNK4 & $\mathbf{0 . 8 5 6}$ & 0.412 & 0.255 & 0.384 \\
DNK5 & $\mathbf{0 . 8 4 3}$ & 0.425 & 0.315 & 0.352 \\
DNK6 & $\mathbf{0 . 8 3 5}$ & 0.487 & 0.209 & 0.419 \\
IEO1 & 0.341 & $\mathbf{0 . 8 1 2}$ & 0.528 & 0.519 \\
IEO2 & 0.436 & $\mathbf{0 . 9 0 6}$ & 0.52 & 0.625 \\
IEO3 & 0.46 & $\mathbf{0 . 8 5 2}$ & 0.585 & 0.636 \\
IEO1 & 0.304 & $\mathbf{0 . 7 9 1}$ & 0.445 & 0.511 \\
IEO2 & 0.476 & $\mathbf{0 . 7 8 1}$ & 0.422 & 0.474 \\
IEO3 & 0.428 & $\mathbf{0 . 7 6 9}$ & 0.404 & 0.455 \\
IEO1 & 0.461 & $\mathbf{0 . 7 7 4}$ & 0.455 & 0.554 \\
IEO2 & 0.504 & $\mathbf{0 . 8 5 5}$ & 0.517 & 0.587 \\
IEO3 & 0.413 & $\mathbf{0 . 7 1 6}$ & 0.441 & 0.584 \\
INK1 & 0.342 & 0.555 & $\mathbf{0 . 9 3 3}$ & 0.486 \\
INK2 & 0.285 & 0.507 & $\mathbf{0 . 9 0 8}$ & 0.458 \\
INK3 & 0.336 & 0.563 & $\mathbf{0 . 9 1 6}$ & 0.531 \\
INK4 & 0.267 & 0.536 & $\mathbf{0 . 8 5 7}$ & 0.411 \\
ISME & 0.494 & 0.685 & $\mathbf{0 . 5 2 4}$ & $\mathbf{1}$ \\
\hline
\end{tabular}

Using Fornell and Larcker approach, the study assesses the discriminant validity. The square root of AVE represented with values on the diagonal in bold were higher than row and column values corresponding to them, explaining correlations between the constructs which indicates that the measures stand discriminant. Thus, table 3 shows that discriminant validity has been established.

Table 3: Discriminant Validity- Fornell and Larcker

\begin{tabular}{lllll}
\hline Constructs & 1 & 2 & 3 & 4 \\
\hline Domestic Network & $\mathbf{0 . 8 2 4}$ & & & \\
International Entrepreneurial & 0.566 & $\mathbf{0 . 7 9 7}$ & & \\
Orientation & & & & \\
International Network & 0.366 & 0.664 & $\mathbf{0 . 8 7}$ & \\
Internationalization of SMEs & -0.14 & 0.279 & 0.167 & $\mathbf{1}$ \\
\hline
\end{tabular}

AVE is represented by the diagonal in bold while the off diagonal entries represent the squared correlation

This study assessed the heterotrait-monotrait ratio (HTMT) to further assess discriminant validity (Hair et al., 2017). The criterion rate used in assessing the correlation is 0.85 $\left(\right.$ HTMT $_{0.85}$ ) (Henseler, Ringle, \& Sarstedt, 2015). Table 4 and figure 2 indicates that, the HTMT results for all the correlations are less than 0.85 suggesting that discriminant validity of the four factor model was established. 
Table 4: Discriminant Validity-Hetrotrait-Monotrait ratio

\begin{tabular}{|c|c|c|c|c|}
\hline \multirow{2}{*}{\multicolumn{5}{|c|}{$\begin{array}{l}\text { Factor } \\
\text { Domestic Network }\end{array}$}} \\
\hline & & & & \\
\hline International Entrepreneurial Orientation & 0.566 & & & \\
\hline International Network & 0.366 & 0.664 & & \\
\hline Internationalization of SMEs & 0.146 & 0.277 & 0.167 & \\
\hline
\end{tabular}

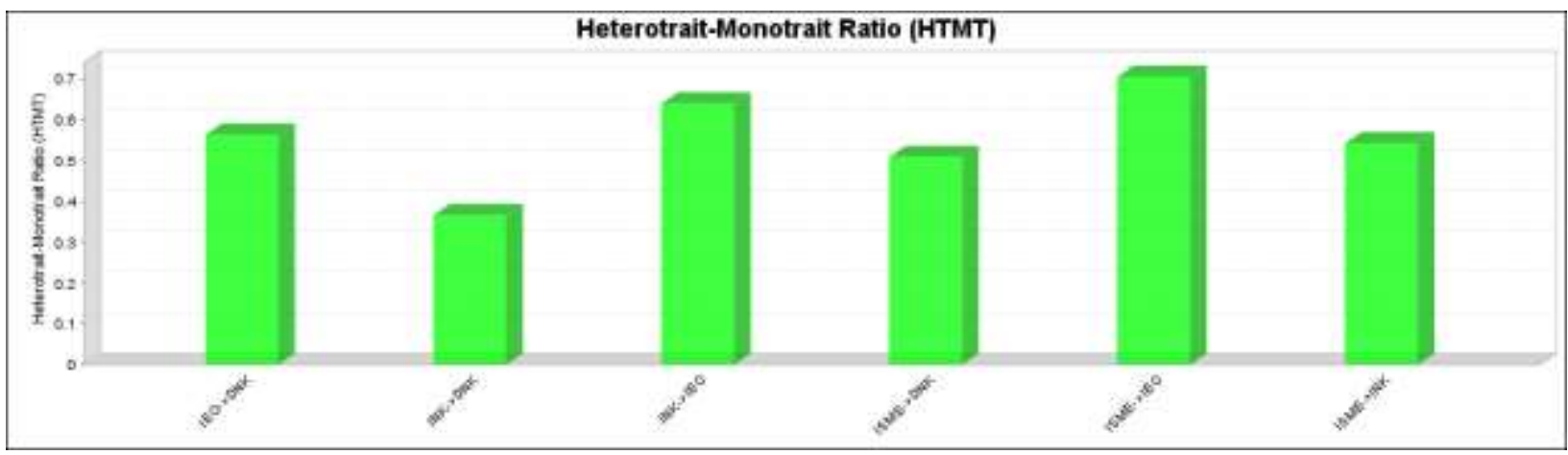

Figure 2: Discriminant validity HTMT Pictorial view

\section{Evaluation of Structural Model}

Structural model assessment in PLS-SEM involves evaluation of the path coefficient and the level of $\mathrm{R}^{2}$. Bootstrapping procedure with 5000 resamples to obtain t-values was performed. It is also required that beside the basic procedures, scholars have to assess predictive relevance $\left(\mathrm{Q}^{2}\right)$ as well as effect sizes $\left(\mathrm{f}^{2}\right)$ (Hair et al., 2017). The study assessed the antecedents to Internationalization directly and through International Entrepreneurial orientation (IEO) as a mediator. Domestic Network $(B=0.177, p<0.000)$ and international Network $(B=0.170, p$ $>0.000$ ) were positive and significantly related to internationalization of SME. The indirect effect of domestic network $(B=0.18, p=0.000$ ) and international network ( $B=0.231, p=$ 0.000) through IEO were positive and significant respectively. Domestic network, international network and IEO account for $51 \%$ variance $\left(R^{2}\right)$ in internationalization of SMEs.

The $R^{2}$ values for internationalization of SMEs (51\%) and mediator construct $(48 \%)$ in the model were moderate values as suggested by (Cohen, 2012) indicating moderate explanatory power of the model. Table 5 provides the summary of the results of structural model analysis showing hypotheses tested. The researchers also assessed effect sizes $\left(f^{2}\right)$ to reveal the existence of effect size of exogenous variable in the endogenous variable $\left(R^{2}\right)$. 


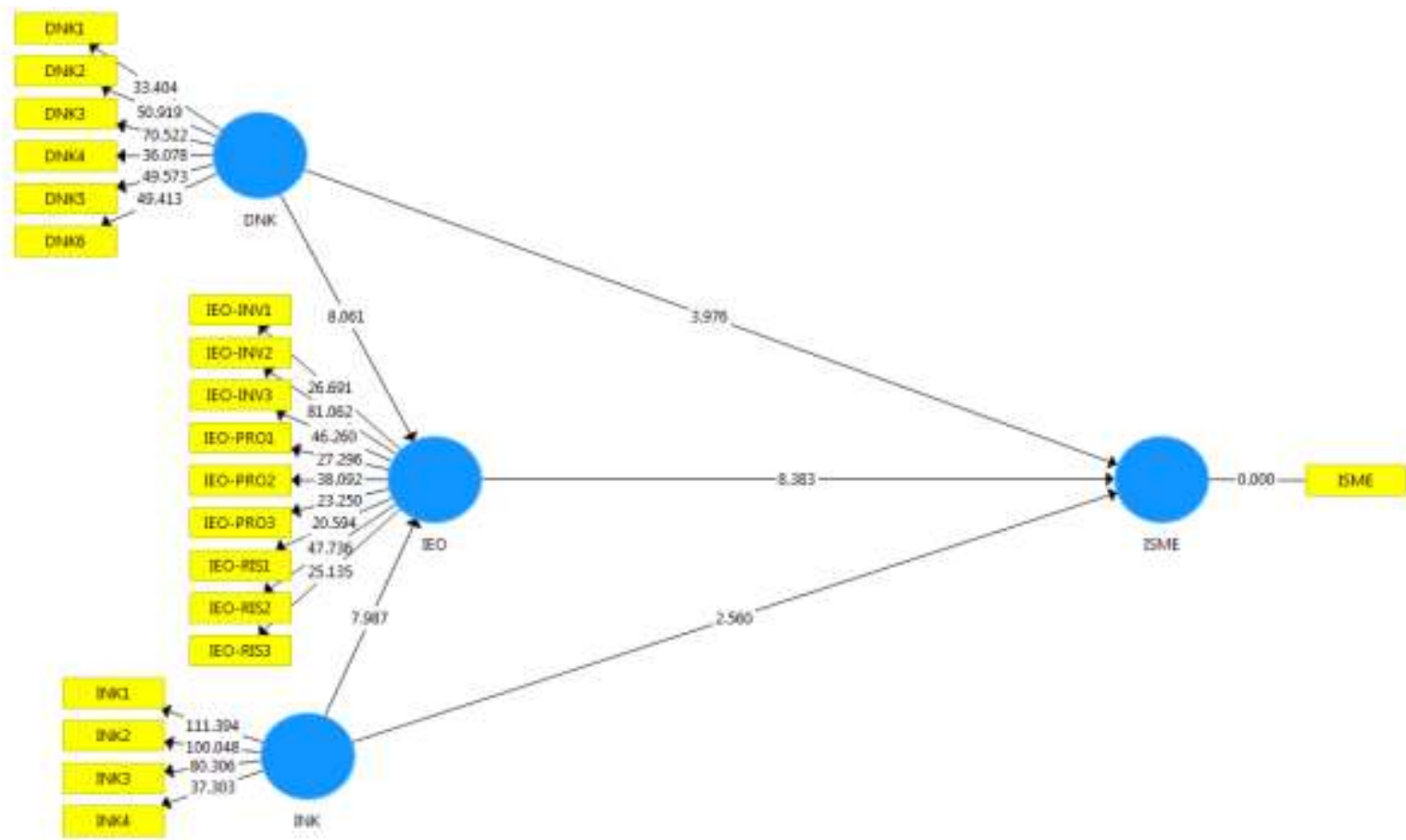

Figure 3: Structural model showing significant path

Effect size assesses whether the removed construct has a functional impact on the dependent construct. In measuring the magnitude of effect size, this study follows (Cohen, 2012) guideline which indicates $0.02,0.15$, and 0.35 , for low, medium, and higher effects respectively. Table 5 , indicates that the $f^{2}$ values in all the relationships displayed differ on the endogenous construct where domestic network (0.046), international network (0.038) and IEO (0.26) demonstrating small and medium effect sizes respectively.

Table 5: Results of the Structural Model Analysis (Hypotheses Testing)

\begin{tabular}{llccccccc}
\hline Hypothesis & Relationships & Path Coefficient & Std Error & T-Values & Decision & R2 & $f^{2}$ & $Q^{2}$ \\
\hline H1 & DNK -> ISME & 0.177 & 0.044 & $3.976^{* * *}$ & Supported & 0.209 & 0.046 & 0.513 \\
H2 & INK -> ISME & 0.170 & 0.051 & $2.560^{* * *}$ & Supported & 0.038 & \\
\hline
\end{tabular}

$* p<0.1, * * p<0.05$ and $* * * p<0.001$

DNK: Domestic Network, INK: International Network, ISME: Internationalization of SME

The researchers used blindfolding procedure to evaluate the predictive relevance of the research model. Blindfolding is a techniques involving sample re-use that omits every dth data point in the indicators of endogenous construct to estimates the parameters by using the remaining data points (Hair et al., 2017; Henseler et al., 2015). Blindfolding procedure must only be applied to endogenous constructs with a reflective measurement model specification as well as to endogenous single-item constructs (Hair et al., 2017). If the $Q^{2}$ value is greater than zero (0), then model has predictive relevance for a certain endogenous construct while the value of 0 and below indicate lack of predictive relevance (Hair et al., 2017). Table 5 indicates that all the $Q^{2}$ values were higher than 0 (0. $\left.289 \& 0.494\right)$ indicating greater predictive relevance. Hair et al., (2017) suggest that, values of $0.02,0.15$, and 0.35 are indication that an exogenous construct has a small, medium, or large predictive relevance for a certain endogenous construct. 


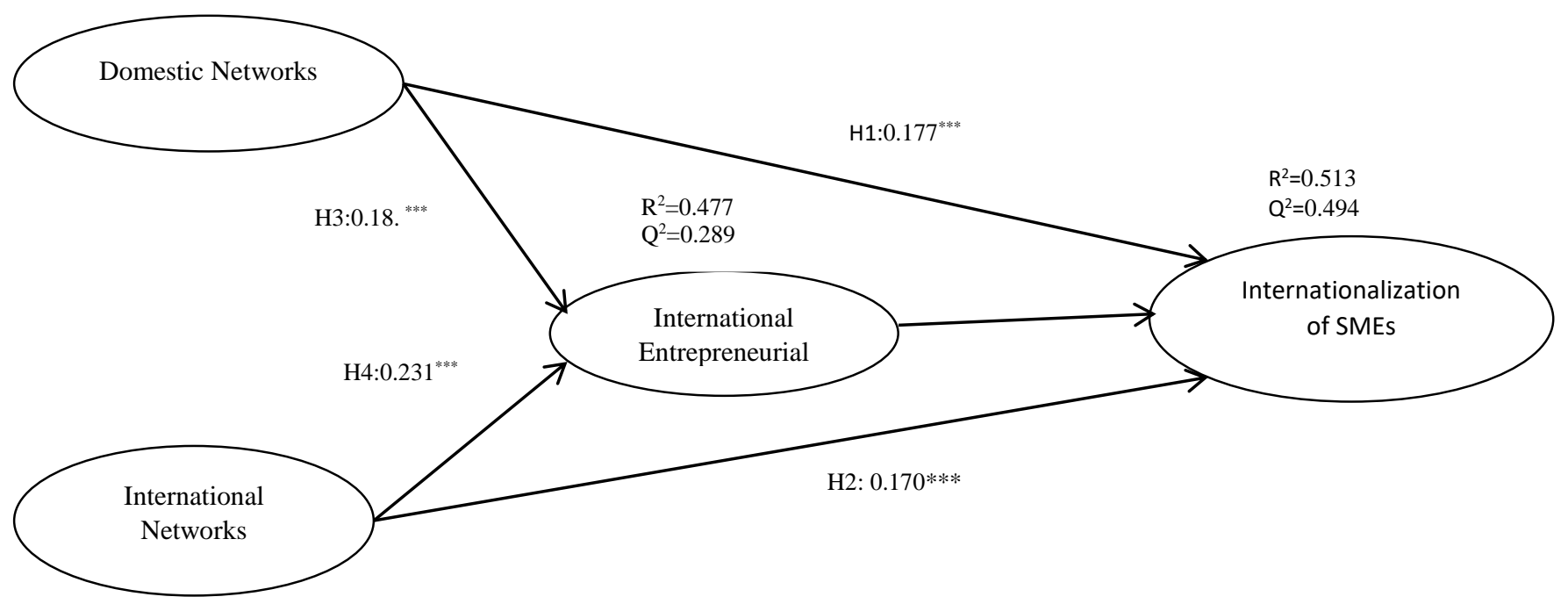

Figure 3: Results from the Structural Model showing significant path and R square values. $* p<0.1, * * p<0.05$ and $* * * p<0.001$.

Finally, the researchers present the results from the assessment of mediating effect of International Entrepreneurial Orientation. Two hypotheses were developed to examine the mediation as follows:

$\mathrm{H}_{3}$ : International Entrepreneurial Orientation mediates the relationship between Domestic Networks and Internationalization of SMEs

$\mathrm{H}_{4}$ : International Entrepreneurial Orientation mediates the relationship between International Networks and Internationalization of SMEs

The study applied the bootstrapping procedure in order assess the mediating effect of IEO. By examining the indirect effect report, the researchers were able to validate if there was a mediation effect. Table 6 presents the indirect effect report. As indicated in the table, the mediating effects of IEO in the relationship between domestic network and ISME $\left(t=5.573^{* * *}\right)$ and international network and ISME $\left(t=5.897^{* * *}\right)$ were significant. The $95 \%$ Bootstrapping Confidence Interval results (Preacher \& Hayes, 2008) $[\mathrm{LL}=0.119, \mathrm{UL}=0.246]$ and $[\mathrm{LL}=0.161$, $\mathrm{UL}=0.315$ ] did not include 0 in between the upper and lower interval suggesting that there was mediation. Thus, the study concluded that the hypotheses $\mathrm{H}_{3}$ and $\mathrm{H}_{4}$ on the mediating effect were supported. Furthermore, because both the directs and indirect effects are significant and point in the same direction, the mediation type is "Complementary Mediation" (Zhao, Lynch, \& Chen, 2010). 
Table 6: Assessment of Mediating Effect of International Entrepreneurial Orientation (IEO)

\begin{tabular}{llllllll}
\hline Relationships & Indirect Effect & $\begin{array}{l}\text { Std } \\
\text { Error }\end{array}$ & CL- Low & CL- Up & $\begin{array}{l}\text { T } \\
\text { values }\end{array}$ & $\begin{array}{l}\text { P } \\
\text { values }\end{array}$ & Decision \\
\hline DNK -> IEO -> ISME & 0.18 & 0.032 & 0.119 & 0.246 & 5.573 & 0.000 & $\begin{array}{l}\text { Supporte } \\
\mathrm{d}\end{array}$ \\
& & 0.039 & 0.161 & 0.315 & 5.897 & 0.000 & $\begin{array}{l}\text { Supporte } \\
\mathrm{d}\end{array}$ \\
\hline INK -> IEO -> ISME & 0.231 & 0.039 & & & & &
\end{tabular}

$* p<0.1, * * p<0.05$ and $* * * p<0.001$

DNK: Domestic Network, INK: International Network, IEO: International Entrepreneurial Orientation, ISME: Internationalization of SME, CL: Confidence Level

\section{Discussion}

The results obtained in this study holds relevant theoretical implications with regard to the networks in international entrepreneurship literature which was carried out by examining the complementary roles of domestic and international networks on internationalization of SMEs and the mediating role of international entrepreneurial orientation. The study also contributes to literature by confirming the conventional views of the mediating role of international entrepreneurial orientation between exogenous and endogenous variables in internationalization studies (Calabro et al., 2017; Etemad, 2004). Using partial least square (PLS) techniques in testing the hypotheses in the model, the measurement component were validated by assessing the validity and reliability. The results indicated that the measures used in the model revealed both discriminant and convergent validity. The researchers assessed the reliability of the measurement model by examining the composite reliability values which again confirmed the reliability of the model.

The result showed that domestic and international networks ware positive and significantly related to internationalization of SME. Although, domestic network appeared to have stronger effect on internationalization of SMEs than international network, their effect is complementary. Moreover, the mediating effect of IEO in the relationship between domestic networks $(B=0.18, p<0.000)$, international network $(B=0.231, p<0.000)$ and internationalization of SME was positive and significant. This result shows IEO as a mechanism in explaining more the relationship between international network, domestic networks and internationalization of SMEs. Furthermore, the study demonstrates how network resource can be accomplished by SMEs when entrepreneurs are committed in enhancing their capabilities in international orientation. For successful development of network relationship at home and in international market by SMEs, this study confirmed that pro-activeness, innovativeness and risk taking behaviors are essential. Firms needs for collaboration with other stake holders in the industry require being aggressive and being proactive in getting the right partners and engage them to strengthen competitiveness. Also unique and new ways of establishing contact with partners and stakeholders can go a long way in making a successful network at home and international markets. Activities of developing collaboration by the firm involve lots of risk taking such as spending on new ways and technology. Entrepreneurs must take moderate risk to form sustainable network at home and abroad. 


\section{Conclusion}

This study demonstrates how crucial business networks are in both domestic and international markets in attaining and sustaining internationalization of SMEs. The results show that SMEs that establish and maintain cluster networks as well as international network have better chances of sustaining presence in the international market. Furthermore, firms with enhanced IEO have the managerial capacity to develop networks more as it plays a significant role in explaining the relationships between networks and internationalization of SMEs. This suggests that, it is important for management of firms to develop risk-taking attitude, innovativeness and pro-activeness necessary to develop network at domestic market as well as in international market for internationalization success. The study holds implications for theory and practice as follows.

\section{Theoretical Implications}

The formation of framework that captures networks in domestic markets and in international markets which were researched separately in previous studies (Ratajczak-mrozek, 2014; Montoro-Sanchez et al., 2018) is a contribution to the argument that firms success in internationalization depend on their ability to develop and maintain strong network at home and in the international market (Lamotte, O., \& Colovic, 2015). This study developed the model incorporating domestic and international network as distinct construct to determine their respective effects on internationalization of SMEs in a single model to offer an insight to literature development on network and internationalization. The result also filled a literature gaps by testing the role of domestic networks as most theoretical and empirical researches concentrate on the understanding of international market determinant factors of internationalization with less attention to domestic market-motivated behaviors (Sanberg, 2014; Lamotte \& Colovic, 2015). Testing mediation in the model lends support for the findings in the previous studies emphasizing the importance of continued discussion on IEO as an additional separate strategic orientation (Covin \& Miller, 2014). Also with IEO as a mediator in the model gives an interesting insight to explore more the intersection between studies on network and international entrepreneurship especially in Sub Sahara African Countries.

\section{Practical Implications}

These findings guide policy makers to focus in developing firm's capacity in international entrepreneurial orientation. Doing this can enhance their ability to establish network at home and abroad for easy access to resources for successful internationalization. From the viewpoint of entrepreneurs and managers, the current work shows the importance of developing management culture and philosophy within the firm, oriented to establishment domestic and international networks with firms at home and abroad respectively. In the same manner, it shows how essential for firms to encourage innovativeness, pro-activeness and risk-taking behaviors among the decision makers of companies. The executives and professionals need to be encouraged to actively explore new business opportunities, take reasonable risks and by being proactive in attending national and international conferences and business exhibitions to enable them establish contacts with suppliers, customers, competitors and other stake holders for future needs and exploit business opportunities.

\section{Limitations of the Study and Future Research}

The study was focused on home government agencies, institutions, national companies and 
exporters association as domestic network while relationship with suppliers, buyers, competitors and institutional networks as international network to estimate internationalization of SMEs. Further studies can explore other features of networks to replicate the study especially in the context of emerging economies. Future studies can also improve on this work by looking at how domestic network and international network relate to each other and factors that build them. Furthermore, IEO was used in this study as a single construct (Calabrò, Campopiano, Basco, \& Pukall, 2017), future studies can use IEO as multidimensional to mediate the relationship. This is to determine the effect of each of the dimensions in the mediation effect in a model.

\section{References}

Calabrò, A., Campopiano, G., Basco, R., \& Pukall, T. (2017). Governance structure and internationalization of family-controlled firms: The mediating role of international entrepreneurial orientation. European Management Journal, 35(2), 238-248. https://doi.org/10.1016/j.emj.2016.04.007

Cohen, J. (2012). Using Effect Size-or Why the P Value Is Not Enough, (September), 279-282.

Coviello, N. E. (2006). The network dynamics of international new ventures, $713-731$. https://doi.org/10.1057/palgrave.jibs.8400219

Covin, J. G., \& Sleven, D. P. (1989). STRATEGIC MANAGEMENT OF SMALL FIRMS IN HOSTILE AND BENIGN ENVIRONMENTS. Strategiic Management Journal, 10(March 1988), 75-87.

Daniel Sullivan. (1993). MEASURING THE DEGREE OF INTERNATIONALIZATION OF A FIRM Daniel Sullivan * University of Delaware Abstract . In spite of both positivistic and instrumental research, the reliability of measuring the degree of internationalization of a firm remains speculat, (October), 325-342.

Dimitratos, P., Voudouris, I., Plakoyiannaki, E., \& Nakos, G. (2012). International entrepreneurial culture - Toward a comprehensive opportunity-based operationalization of international entrepreneurship. International Business Review, 21(4), 708-721. https://doi.org/10.1016/j.ibusrev.2011.08.001

Felzensztein, C., Ciravegna, L., Robson, P., \& Amorós, E. (2015). The international strategy of Latin American SMEs: the effects of networks and entrepreneurship orientation. J Small Bus Manag, 53(51), (S1), 145-160.

Felzensztein, C., Ciravegna, L., \& Robson, P. (2015). Small and Medium Enterprises, 53, 145160. https://doi.org/10.1111/jsbm.12188

Fink, M., Harms, R., \& Kraus, S. (2008). Cooperative internationalization of SMEs : Selfcommitment as a success factor for International Entrepreneurship. European Management Journal, 26(6), 429-440. https://doi.org/10.1016/j.emj.2008.09.003

Fink, M., \& Kraus, S. (2007). Mutual trust as a key to internationalization of SMEs. Management Research News, 30(9), 674-688. https://doi.org/10.1108/01409170710779980

Fletcher, R. (2008). The internationalisation from a network perspective : A longitudinal study is. Industrial Marketing Management, 37(8), 953-964.

https://doi.org/10.1016/j.indmarman.2007.09.008

Henseler, J., Ringle, C. M., \& Sarstedt, M. (2015). A new criterion for assessing discriminant validity in variance-based structural equation modeling, 115-135.

https://doi.org/10.1007/s11747-014-0403-8 
Hohenthal, J., Johanson, J., \& Johanson, M. (2014). Network knowledge and businessrelationship value in the foreign market. International Business Review, 23(1), 4-19. https://doi.org/10.1016/j.ibusrev.2013.08.002

Holm, D. B., Eriksson, K., \& Johanson, J. (1996). Business Networks and Cooperation in International Business Relationships. Journal of International Business Studies, 27(4), 1033-1053. https://doi.org/10.1057/palgrave.jibs.8490162

Javalgi, R. G., \& Todd, P. R. (2011). Entrepreneurial orientation, management commitment, and human capital: The internationalization of SMEs in India. Journal of Business Research, 64(9), 1004-1010. https://doi.org/10.1016/j.jbusres.2010.11.024

Johanson, J., \& Vahlne, J. (2009). The Uppsala internationalization process model revisited: From liability of foreignness to liability of outsidership. Journal of International Business Studies, 40(9), 1411-1431. https://doi.org/10.1057/jibs.2009.24

Joseph F. Hair, J., Hult, G. T. M., Ringle, C. M., \& Rstedt, M. S. (2017). Partial least squares structural equation modeling (PLS-SEM). European Business Review. Washington DC: SAGE publihers. https://doi.org/10.1108/EBR-10-2013-0128

Karage, A. I., Yusof, R. N. R., Nadarajah, D., \& Abdul, M. (2019). Complementary Roles of Domestic and International Networks in Sustaining Internationalization of SMEs: a Modeling Approach. International Journal of Academic Research in Business and Social Sciences, 9(8), 156-175.

Khalili, H., Nejadhussein, S., \& Fazel, A. (2013). The influence of entrepreneurial orientation on innovative performance Study of a petrochemical company in Iran. Journal of Knowledge-Based Innovation in China, 5(3), 262-278. https://doi.org/10.1108/JKIC-092013-0017

Kontinen, T., \& Ojala, A. (2011). International Opportunity Recognition among Small and Medium-Sized Family Firms. Journal of Small Business Management, 49(3), 490-514. https://doi.org/10.1111/j.1540-627X.2011.00326.x

Kumar, V., \& Singh, N. (2008). Internationalization and Performance of Indian Pharmaceutical Firms. Published Online in Wiley InterScience, 50(5), 321-330. https://doi.org/10.1002/tie.20217

Lamotte, O., \& Colovic, A. (2015). (2015). Early internationalization of new ventures from emerging countries: The case of transition economies. M@N@Gement, 18(1), 8-30.

Lee, M., Yin, X., Lee, S., Weng, D. H., \& Peng, M. (2014). The impact of home country institutions on new venture export: examining new ventures in transition economies. International Entrepreneurship and Management Journal, 11(4), 823-848. https://doi.org/10.1007/s11365-014-0316-5

Lin, K., \& Chaney, I. (2007). The Influence of Domestic Interfirm Networks on the Internationalization Process of Taiwanese SMEs, 13(4), 565-583. https://doi.org/10.1080/13602380701345499

Manolova, T. S., Manev, I. M., \& Gyoshev, B. S. (2010). In good company: The role of personal and inter-firm networks for new-venture internationalization in a transition economy. Journal of World Business, 45(3), 257-265. https://doi.org/10.1016/j.jwb.2009.09.004

Marinova, S., Child, J., \& Marinov, M. (2015). The role of home governments in outward foreign direct investment. In Institutional Impacts on Firm Internationalization. Palgrave Macmillan UK. Chicago, 173-189. https://doi.org/10.1057/9781137446350_8

Milanov, H., \& Fernhaber, S. A. (2014). When do domestic alliances help ventures abroad? Direct and moderating effects from a learning perspective. Journal of Business Venturing, 
29(3), 377-391. https://doi.org/10.1016/j.jbusvent.2013.05.004

Molina-morales, F. X., \& Teresa, M. (2010). Social networks: effects of social capital on firm innovation. Journal of Small ..., 48(2), 258-279. https://doi.org/10.1111/j.1540627X.2010.00294.x

Montoro-Sanchez, A., Diez-Vial, I., \& Belso-Martinez, J. A. (2018). The evolution of the domestic network configuration as a driver of international relationships in SMEs. International Business Review, 27(4), 727-736.

https://doi.org/10.1016/j.ibusrev.2017.08.003

Oparaocha, G. O. (2015). SMEs and international entrepreneurship : An institutional network perspective. International Business Review.

https://doi.org/10.1016/j.ibusrev.2015.03.007

Pla-Barber, J., \& Escribá-Esteve, A. (2006). Accelerated internationalisation: evidence from a late investor country. International Marketing Review, 23(3), 255-278. https://doi.org/10.1108/02651330610670442

Preacher \& Hayes. (2008). Asymptotic and resampling strategies for assessing and comparing indirect effects in multiple mediator models. Behavior Research Methods, 40(3), 879891. https://doi.org/10.3758/BRM.40.3.879

Preacher, K. J., \& Hayes, A. F. (2008). Asymptotic and resampling strategies for assessing and comparing indirect effects in multiple mediator models. Behavior Research Methods, 40(3), 879-891. https://doi.org/10.3758/BRM.40.3.879

Ratajczak-mrozek, M. (2014). THE INSIGHT INTO RELATIONSHIP STRENGTH FROM A DOMESTIC AND INTERNATIONAL PERSPECTIVE - WHEN A RELATIONSHIP IS " AN IMPORTANT RELATIONSHIP "? THE INSIGHT INTO RELATIONSHIP STRENGTH FROM WHEN A RELATIONSHIP IS " AN IMPORTANT RELATIONSHIP "? Paweł Mielcarek Magdalena Herbeć Filip Nowacki, (September). https://doi.org/10.13140/2.1.2993.6008

Ripollés-Meliá, M., Menguzzato-Boulard, M., \& Sánchez-Peinado, L. (2007). Entrepreneurial orientation and international commitment. Journal of International Entrepreneurship, 5(3-4), 65-83. https://doi.org/10.1007/s10843-007-0016-0

Simonin, B. L. (1997). No Title The importance of collaborative know-how: An empirical test of the learning organization. Academy of Management Journal, 4O(5), 1150-1174.

Sullivan, D. M., \& Ford, C. M. (2014). How entrepreneurs use networks to address changing resource requirements during early venture development. Entrepreneurship: Theory and Practice, 38(3), 551-574. https://doi.org/10.1111/etap.12009

Sundqvist, S., Kyläheiko, K., Kuivalainen, O., \& Cadogan, J. W. (2012). Kirznerian and Schumpeterian entrepreneurial-oriented behavior in turbulent export markets. International Marketing Review, 29(2), 203-219.

https://doi.org/10.1108/02651331211216989

Swoboda, B., \& Olejnik, E. (2016). International Entrepreneurial Orientation, 54(1), 139-161. https://doi.org/10.1111/jsbm.12135

Szyliowicz, D., \& Galvin, T. (2010). Applying broader strokes: Extending institutional perspectives and agendas for international entrepreneurship research. International Business Review, 19(4), 317-332. https://doi.org/10.1016/j.ibusrev.2010.01.002

Wach, K. (2015). Entrepreneurial Orientation and Business Internationalisation Process : The Theoretical Foundations of International Entrepreneurship, 3(2), 9-24. https://doi.org/10.15678/EBER.2015.030202

Yoeh, P.-L. (2004). International learning: antecedents and performance implications among 
newly internationalizing companies in an exporting context. International Marketing Review, 31(4/5), 511-535.

https://doi.org/http://dx.doi.org/10.1108/09564230910978511

Zain, M., \& Ng, S. I. (2006). The impacts of network relationships on SMEs' internationalization process. Thunderbird International Business Review, 48(2), 183-205. https://doi.org/10.1002/tie.20092

Zhao, X., Lynch, J. G., \& Chen, Q. (2010). Reconsidering Baron and Kenny: Myths and Truths about Mediation Analysis. Source Journal of Consumer Research, 37(2), 197-206. https://doi.org/10.1086/651257 